\title{
A abertura política através dos filmes de Os Trapalhões na década de 1980
}

\author{
Maria Ignês Carlos Magno \\ Doutora em Ciências da Comunicação pela Escola de Comunicações e Artes da Universidade \\ de São Paulo (ECA-USP) e professora do Programa de Pós-Graduação em Comunicação da \\ Universidade Anhembi Morumbi. \\ E-mail: unsigster@gmail.com
}

André Gustavo de Paula Eduardo

Doutorando em Comunicação pela Universidade Anhembi Morumbi e Mestre em Comunicação pela Universidade Estadual Paulista (Unesp).

E-mail: agpe13@yahoo.com.br

Felipe Abramovictz

Doutorando em Multimeios pela Universidade Estadual de Campinas (Unicamp), mestre pelo Programa de Comunicação da Universidade Anhembi Morumbi. Bacharel em Comunicação e Multimeios pela PUC-SP.

E-mail: fabramovictz@uol.com.br

Resumo: Discute-se neste artigo a presença de elementos de ordem política e social dento de parte da filmografia da trupe de humoristas Os Trapalhões, especialmente em obras realizadas na década de 1980 que carregam em alusões e até motivos críticos - ainda que permeados por ambiguidades - sobre o processo em curso da Abertura Política, no qual o Brasil deixava o período militar rumo à redemocratização. Para tanto, recorreremos a três estudos de caso bastante particulares em meio aos filmes estrelados pelo grupo: Os Saltimbancos Trapalhões (1981), Os Trapalhões na Serra Pelada (1982), ambos dirigidos por J.B. Tanko, e Os Trapalhões e o Mágico de Oróz (Dedé Santana e Victor Lustosa, 1984).

Palavras-chave: cinema brasileiro; abertura política; Os Trapalhões; redemocratização.
Abstract: The presence of political and social elements within the filmography of the comedian troupe Os Trapalhões is discussed in this article, especially in three works filmed during the1980s that carry allusions and even critical motives although permeated by ambiguities - on the process of Political Open, in which Brazil was leaving the military period towards redemocratization. Therefore, we will reflect on three very particular cases amidst the films starred by the group: Os Saltimbancos Trapalhões (1981), Os Trapalhões na Serra Pelada (1982), both directed by JB Tanko, and Os Trapalhões e o Mágico de Oróz (Dedé Santana and Victor Lustosa, 1984).

Keywords: brazilian cinema; political open; Os Trapalhões; redemocratization. 


\section{INTRODUÇÃO}

Época de grande mobilização da sociedade civil no Brasil, a primeira metade dos anos 1980 é marcada por um momento em que o processo em direção à redemocratização do país caminhava, entre avanços e recuos. Desde o fim da década anterior, o processo de Abertura Política, anunciado desde 1974, foi marcado pelo ressurgimento das organizações sindicais, do movimento estudantil e pela derrocada do discurso do "milagre econômico", dadas as taxas de crescimento cada vez mais baixas e a significativa queda de popularidade na base de apoio do regime, inclusive por parte do empresariado. $\mathrm{O}$ cinema direcionado para crianças ou "cinema infantil", como definido por $\mathrm{Melo}^{1}$, então com larga trajetória ${ }^{2}$ na produção audiovisual brasileira, também responde a este contexto ${ }^{3}$, o que, em alguns casos como Maneco, o super tio (Flávio Migliaccio, 1978) ou mesmo Paspalhões e Pinóquio 2000 (Victor Lima, 1982) inclui uma série de alusões a regimes repressivos que são derrotados por meio de uma sublevação de caráter popular, ecoando, por vezes, através de uma chave alegórica os processos políticos em curso.

Neste contexto do fim da década de 1970 e início dos anos 1980, certas temáticas sociais, antes pouco recorrentes nos filmes estrelados por um dos grupos de mais longeva trajetória no cinema brasileiro, os Trapalhões, passam a atravessar de forma recorrente a sua filmografia no início dos anos 1980, ainda que com certas ambiguidades. Desta forma, produções marcadas pela paródia escrachada de filmes e séries televisivas recém-lançadas e clássicos da literatura infanto-juvenil $^{4}$ passam a ter como temática central problemáticas nacionais que resvalam no horizonte político e social, sem, porém, se distanciar do horizonte de deglutição autorreferencial que caracteriza toda a filmografia do grupo na qual

[...] acumulam-se pedaços de gêneros, num esforço de deglutição que parece querer aproveitar ao máximo a oportunidade de utilizar as ricas condições de produção. [...] Temática nacional, mas agora com recursos da própria produção americana, coisa sequer imaginada na chanchada ou nos Trapalhões nos anos 70 .

Ainda que este horizonte estivesse presente em algumas das produções estreladas pela trupe desde o início da Abertura, em filmes como Os saltimbancos Trapalhões (1981), Os Trapalhões na Serra Pelada (1982), dirigidos por J.B. Tanko, e Os Trapalhões e o Mágico de Oróz (1984, Dedé Santana e Victor Lustosa) se destaca um horizonte de reempoderamento popular que aponta para um país em transformação, o que se dá, como veremos, em meio a uma mistura de gêneros e elementos paródicos entremeadas a referências das mais diversas ao contexto do país. Em comum, nota-se como em todos eles um mote comum: a ambiência em determinada localidade marcada pelo autoritarismo e pela repressão que é, por fim, derrotada, ou ao menos, contrariada, por forças populares organizadas.

Muito permeável às questões do seu tempo, que aparecem deglutidas em meio a um emaranhado tecido intertextual, é também frequente (por paradoxal que pareça) a presença de adulações a medidas governamentais, como visto na menção aos interventores militares na cartela inicial de Os Trapalhões na Serra Pelada (1982)
1. MELO, João Batista. Lanterna mágica: infância e cinema infantil. Rio de Janeiro: Civilização Brasileira, 2011.

2. Trajetória esta que, para além dos filmes estrelados pelos Trapalhões, certamente incluiria casos pioneiros como Jonjoca, o Dragãozinho Manso (Humberto Mauro, 1942), O Saci (Rodolfo Nanni, 1951), Pluft, o fantasminha (Romain Lessage, 1962) e, já sob a vigência da Ditadura Militar, filmes como No Tempo dos Bravos (Wilson Silva, 1964), A Dança das Bruxas (Francisco Dreux, 1970), Meu Pé de Laranja Lima (Aurélio Teixeira, 1970), As Aventuras com Tio Maneco (Flávio Migliaccio, 1975), As Quatro Chaves Mágicas (Alberto Salvá, 1972), A Pequena Órfã (Clery Cunha, 1972), Piconzé (Ypê Nakashima, 1972), O Detetive Bolacha Contra o Gênio do Crime (Tito Teijido, 1973) e O Picapau Amarelo (Geraldo Sarno, 1973).

3. No período da Abertura Política, para além dos citados e dos filmes estrelados pelos Trapalhões, poderíamos situar longas como O Caçador de Fantasmas (Flávio Migliaccio, 1975), Uma Aventura na Floresta Encantada (Mário Latini, 1977), Maneco, o super tio (Flávio Migliaccio, 1978), Dani, um Cachorro Muito Vivo (Frank Dawe, 1979), As Aventuras da Turma da Mônica (Maurício de Souza, 1982), Os Três Palhaços e o Menino (Milton Alencar, 1982) e O Cavalinho Azul (Eduardo Escorel, 1984). 
4. A estratégia de hibridação de gêneros encontra bons exemplos na construção dos filmes da trupe Os Trapalhões, tal como em Os Trapalhões na Guerra dos Planetas (Adriano Stuart, 1978), O Cangaceiro Trapalhão (Daniel Filho, 1983) e diversos outros, caso de Paspalhões e o Pinóquio 2000 (Victor Lima, 1982). Identificamos a presença da paródia como fator central na condução das tramas, atuando como chamariz do público infantil e garantindo um processo de ressignificação de códigos que, realocados, adquirem novos sentidos, todos em prol dentro desse olhar infantil. Em O Cangaceiro TrapaIhão, por exemplo, evoca-se um clássico do cinema brasileiro, O Cangaceiro (Lima Barreto, 1953) bem como toda uma tradição de filmes que trazem personagens históricos como Lampião e Maria Bonita, e ao mesmo tempo traz o diálogo com a televisão e ao mesmo tempo, por conta da minissérie Lampião e Maria Bonita exibida pela Rede Globo um ano antes. Como de praxe, não faltam citações à cultura pop e a filmes de grande bilheteria caso de Os Caçadores da Arca Perdida (Steven Spielberg, 1981). Os filmes da trupe traziam referências constantes a fatos do cotidiano brasileiro: o folclore, o cordel, e em outras produções, os recursos naturais, eventos históricos como o choque do petróleo e a Abertura Política, o futebol, o carnaval, a economia, a inflação, dentre outros temas.

5. RAMOS, José Mario Ortiz. Cinema, televisão e publicidade: cultura popular de massa no Brasil nos anos 1970-1980. São Paulo: Annablume: 2004. p. 139. e, especialmente, nas inúmeras referências ao Pró-Álcool ${ }^{6}$ que permeiam $O$ incrível monstro trapalhão (1980), trama na qual um cientista, Dr. Jegue (Renato Aragão), descobre uma fórmula capaz de substituir o combustível à base de petróleo por um composto que inclui o álcool e se recusa de entregar a "fórmula" para os "estrangeiros" (representado por vilões russos e árabes), optando, mesmo com os ataques e reprimendas sofridos, a celebrar um "acordo" de cooperação na Esplanada dos Ministérios. Por outro lado, situações que poderiam ser lidas como subversivas ou ambíguas pelos sistemas de repressão também costuram determinadas situações ao longo da filmografia do grupo, seja em A filha dos trapalhões (1984, Dedé Santana), quando empresários que ganham a vida vendendo crianças dizem que estão "resolvendo um problema social", ou na contundente cena na qual um ricaço, sem razões aparentes para além de um preconceito de classe, tenta "derrubar a tiro" o barraco onde os protagonistas vivem, o que o faz a bordo de um iate com garotas de biquíni que nada fazem para impedi-lo, assim como nas sequências de Os Trapalhões no Planalto dos Macacos (1976), em que os personagens, após acreditarem que caíram em um "outro planeta", passam a enfrentar um grupo que não os aceita por serem diferentes e fazem uso político da recepção dada pela rainha para ameaçar a monarca com o objetivo de tomar o poder com o argumento de que isto seria um "um perigo para a nossa tradição e a nossa sociedade" e à "conservação dos nossos costumes e nossa cultura". Em paralelo, é introduzida no filme uma discussão crítica sobre certa sociedade de consumo, questão esta que carrega certo paradoxo, já que a obra em si é um produto da indústria cultural que inclusive inclui, sem culpa, inserts publicitários em cena em diversas ocasiões. Estas contradições são ressaltadas por $\mathrm{Melo}^{7}$, que destaca que tais obras

[...] muitas vezes açambarcam posições ideológicas conflitantes [...]. São filmes que criticam a violência, mas a mostram, criticam a acumulação de riquezas, mas a incluem como um atributo dos personagens. [...] Isso pode ser percebido em certos discursos 'subversivos' em relação ao sistema convivendo com um reforço desse mesmo sistema.

Em meio a tais exemplos, há que se destacar como se sobressai certa "serialidade" na comparação das estruturas dramáticas das narrativas, que se constituem em um modelo estrito e bastante fechado, de fortes implicações mercadológicas, e que é, certamente, muito particular nos filmes estrelados e produzidos pelo grupo. Portanto, em meio a uma filmografia na qual a repetição da fórmula tende a se impor sobre a particularidade das obras, a definição de um corpus que reverbera para um horizonte de anseios de transformação social passa, necessariamente, por situar de forma mais precisa "tanto as coerções do processo industrial na fabricação desse tipo de ficção, como os desejos de um público infantil e popular" aos quais esses filmes respondem.

\section{OS TRAPALHÕES E AS TEMÁTICAS NACIONAIS NO INÍCIO DOS ANOS 1980}

Fenômeno ímpar no cenário da indústria cultural brasileira, em especial pelas multifacetárias relações suscitadas pelo entrelaçamento entre o mundo pop, 


\section{A abertura política através de Os Trapalhões \\ - Maria Ignês Carlos Magno, André Gustavo de Paula Eduardo e Felipe Abramovictz}

a televisão e o mercado audiovisual, os Trapalhões estrelam até hoje 43 filmes (aproximadamente metade deles com o quarteto completo), inúmeros programas televisivos semanais e, se nos concentrarmos somente no intervalo entre 1979 e $1984^{9}$, nota-se 13 lançamentos cuja direção fica a cargo de realizadores diversos ${ }^{10}$. Inserem-se múltiplas menções das mais diversas da cultura brasileira (do cangaço ao futebol, do Auto da Compadecida, de Ariano Suassuna, ao garimpo da Serra Pelada), que se aliam a referenciais frequentes na trajetória pregressa da trupe, que envolvia o caótico e recorrente dialogo intertextual com filmes e séries de sucesso da época (Star wars, Indiana Jones, O planeta dos macacos) - sem se apegar "à totalidade da obra [...] para construir o registro cômico ${ }^{11}$ e popular" ${ }^{12}$ - e um diálogo muito próximo com a TV, incorporando com frequência outros ícones pop televisivos no elenco. Ortiz Ramos destaca como tal "mistura de elementos díspares se adéqua bem ao 'gosto popular"'13 e caracteriza uma "recepção fragmentada, distraída, festiva" ${ }^{4}$, de forte apelo com o público e, ao mesmo tempo, como destaca Melo $^{15}$, muito ligado aos aparatos da indústria cultural.

Se voltarmos aos Trapalhões notaremos que essa fragmentação é muito mais intensa e 'selvagem' nos filmes dos anos 70, sofrendo um processo de disciplinamento, sem, no entanto, desaparecer nem diminuir nos anos 80 . Seus espectadores, crianças e público popular, operam com esses cacos - 'brincam' [...] conforme a inserção em cada época e conforme seu posicionamento social. São constantes as acusações ao grupo de fazer piadas carregadas de preconceitos, [...] mas são articuladas com outros elementos que minam o universo dos poderosos, com doses de rebeldia e inclusive com uma postura que pretende a crítica social. A análise crítica dos filmes do grupo deve estar, portanto, atenta para essa contraditoriedade, e para as possibilidades de combinações diversas dos espectadores. É fundamental pensarmos sempre na articulação de dois planos de fragmentação - das produções e das formas de pensar e agir populares - para compreendermos o fluxo de vitalidade que conecta esses filmes com seus espectadores ${ }^{16}$.

Em meio a filmes entremeados a uma série quase contínua de quiproquós pouco delineados, em um ritmo veloz, e recheados de menções das mais diversas (raptos, disfarces, peripécias, desenfreado), a repetição de fórmulas conhecidas torna-se um elemento de fruição:

A filmografia dos Trapalhões é toda construída com a repetição de estruturas, elementos, situações. A narrativa e a alocação dos personagens seguem na maioria dos filmes um modelo fixo: o herói/cômico principal e os 3 companheiros enfrentam um antagonista/vilão e seus asseclas, sendo que após uma série de enfrentamentos os derrotam. Complementando o quadro há a heroína [...] por quem o herói sempre se apaixona. Se existir o galã, ou "herói verdadeiro", esse amor está fadado ao insucesso e terminará solitário. [...] A inspiração chapliniana ${ }^{17}$ é clara: Aragão protagonizando tipos humildes e solidários que vencem o jogo com os poderosos ${ }^{18}$.

Mesmo em meio aos novos direcionamentos da carreira da trupe a partir do início dos anos 1980, quando temas cinematográficos modernizados e temas literários estrangeiros dão lugar a temáticas sociais que reverberam diretamente questões nacionais latentes, tal esquema mantêm-se rigorosamente da mesma
6. Programa, inicialmente lançado em novembro de 1975, criado pelo governo federal com o objetivo de favorecer a substituição dos carros movidos por derivados de petróleo pelo combustível feito à base de álcool, tendo grande papel econômico no fim dos anos 1970 e início dos 1980. Anos mais tarde, porém, com a gradativa diminuição dos preços do barril de petróleo em um cenário em que a crise do petróleo estava mais distante e o crescente preço da cana-de-açúcar no mercado, o projeto tornou-se menos vantajoso.

7. MELO, João Batista. op. cit., 2011. p. 155.

8. RAMOS, José Mario Ortiz. op. cit., 2004. p. 152.

9. Momento também marcado por uma crise no grupo por disputas financeiras internas que foi responsável pelo rompimento de Mussum, Dedé Santana e Zacarias com Renato Aragão em 1982. Neste momento, os três primeiros lançam, por meio de uma produtora própria, a DEZUMA, o filme Atrapalhando a Suate (1983) e, na TV estrelam um programa próprio, A Festa é Nossa, e Renato Aragão, seguindo com o programa semanal televisivo, lança $O$

Trapalhão na Arca de Noé (1983). O quarteto voltaria a se reunir poucos meses depois.

10. Entre os quais o veterano J.B. Tanko, colaborador mais frequente, assim como de nomes como Adriano Stuart, Daniel Filho, Del Rangel, Vítor Lustosa e o próprio Dedé Santana. A estes soma-se o caso de SilvioTendler que faria um documentário sobre a trupe.

11. Sobre o caráter popular do humor da trupe, ver CARRICO, André. Os Trapalhões no Reino da Academia: revista, rádio e circo na poética trapalhônica. 2013. Tese (Doutorado em Artes) - Unicamp, Campinas.

12. RAMOS, José Mario Ortiz. op. cit., 2004. p. 132. 
13. Ibidem. p. 149.

14. Ibidem. p. 152.

15. MELO, João Batista. op. cit., 2011.

16. RAMOS, José Mario Ortiz. op. cit., 2004. p. 150.

17. Referência citada diretamente em filmes como Bonga, o Vagabundo (1969) e A Filha dos Trapalhões (1984), cujo enredo faz diversas menções à O Garoto (Charlie Chaplin, 1921).

18. RAMOS, José Mario Ortiz. op. cit., 2004. p. 143.

19. Ibidem. p. 131.

20 lbidem.

21 lbidem. p. 133

22. Tanto Os Saltimbancos Trapalhões (1981) quanto Os Trapalhões na Serra Pelada (1982) foram vistos por mais de 5 milhões de espectadores. Oróz, por sua vez, teve um público próximo de 2,5 milhões de pessoas. Para além da bilheteria, há que se destacar também a presença de Gilvan Pereira como co-roteirista nos três casos citados, diretor de obras como o contundente Os Sensuais - Crônica de uma família pequeno burguesa (1977)

23. Nestes exemplos, a exploração da mão de obra em geral e a figuração de regimes autoritários e, no caso de Oroz e Serra Pelada, respectivamente, de forma mais particularizada, da seca que aflige parte da região nordeste e das condições de vida dos garimpeiros no sul do Pará. forma, sem que haja qualquer intenção de tensionar "o acordo que se estabelecia entre eles e o espectador, [...] o ato cultural mais vivo" ${ }^{19}$ de um projeto de cinema popular com o qual o grupo se filia, "inseparável da passividade consumidora" 20 e que, antes de tudo, preocupava-se em garantir que o horizonte de expectativas do público fosse sempre atendido.

Em um momento em que a Abertura Política parecia se consolidar, a produção do grupo, ainda que sem deixar de lado certas ambiguidades, mostra-se imbricada no contexto em que as insatisfações populares eram cada vez mais presentes e as consequências da crise econômica se agravam com a alta da inflação. Tais questões se fazem mais e mais presentes nos filmes, que não se furtam de apontar uma saída que responde a tais anseios populares, e levam às telas uma série de problemáticas sociais:

[...] a exploração dos artistas pelo dono do circo, em os Saltimbancos trapalhões (1981), a preocupação com os menores abandonados em Os Vagabundos Trapalhões (1981) [...], a questão ecológica, em O trapalhão na arca de Noé (1983), ambientado no pantanal matogrossense com sua fauna em extinção; o Nordeste e sua seca, em Os trapalhões e Mágico de Oroz (1984) que inclusive termina com um apelo "à autoridades" para não esquecerem a religião; os "cartolas" e seus interesses, em $O s$ trapalhões e o rei do futebol (1986) ${ }^{21}$.

Deste conjunto de obras aqui citadas, três filmes mostram-se casos bem especiais ao reverberar diretamente o contexto do país em um momento de redemocratização, evidenciado pelo horizonte social ao qual o filme aponta na derrota do tirânico modelo de governança de um circo gerido por meio da coerção sem que os empregados, constantemente vigiados por um grupo de capangas uniformizados, tenham condições mínimas de exercer seu ofício em Os saltimbancos Trapalhões (1981); do ganancioso empresário que domina o garimpo, o que o faz às margens da lei com ajuda de seu exército de seguranças em Os Trapalhões na Serra Pelada (1982); e no empresário/“coronel”, que cobra para que a população tenha acesso à água em Os Trapalhões e o Mágico de Oróz (1984) ${ }^{22}$. Portanto, o que os torna casos bastante particulares não é a temática social ${ }^{23}$ - questão que ecoa de diversas maneiras em muitos dos seus filmes - nem na maneira como os protagonistas subvertem as estruturas de poder (seja de empresários ou representantes do setor público) ou mesmo as citações pontuais ao contexto político que poderiam ser, momentaneamente, interpretados como subversivos, também recorrentes, em maior ou menor grau, pela especificidade que caracteriza a permeabilidade deste cinema com o contexto em que é realizado, mas sim como, em comum, nas três obras aponta-se para um horizonte de liberdades por meio da organização das classes trabalhadoras em resposta a uma situação autoritária que, invariavelmente, ainda que particularizada nas experiências dos personagens dos filmes, se referencia a um contexto mais amplo do processo de redemocratização. 


\section{OS SALTIMBANCOS TRAPALHÕES: O POVO DE VOLTA ÀS PRAÇAS}

A partir de uma referência direta do musical Os saltimbancos (adaptação de Chico Buarque ${ }^{24}$ da versão original italiana, encenada pela primeira vez em 1977), Os saltimbancos Trapalhões (1981), de J. B. Tanko, traz uma trama que, ao satirizar a repressão, evoca um horizonte de reemponderamento popular que ecoa diretamente o contexto da Abertura Política. O filme é ambientado em um circo, o Grande Circo Bartholo, controlado pelo Barão (Paulo Fortes) e seus comparsas (caso do hipnotizador Assis Satã e sua assistente, Tigrana) onde, pouco a pouco, o número circense de quatro funcionários (Didi, Dedé, Mussum e Zacarias), que antes trabalhavam apenas nos bastidores, torna-se o grande sucesso da companhiao patrão passa a explorá-los ainda mais, o que faz com que passem a lutar por condições mais dignas para exercer o seu próprio ofício. Empregados pelo ganancioso Barão em uma condição de trabalho semi-escravo (em que devem trabalhar até pagarem os supostos "prejuízos"), Os Trapalhões aliam-se ao acrobata Frank (Mário Cardoso) e ganham a simpatia de sua namorada, a filha do dono do circo, Karina (Lucinha Lins), por quem Didi (Renato Aragão) é apaixonado.

Há, no filme, um percurso que vai da apatia à ação, em que os trabalhadores, pouco a pouco, se organizam e se mobilizam para reagir ao contexto opressivo a eles imposto, na qual o Barão exige que permaneçam em condições cada vez mais precárias, incluindo a alimentação (o que faz os empregados precisarem até furtar uma galinha por não mais suportarem a má qualidade das refeições). Pressionados, Didi fala em uma reunião de "sindicato" para tomarem uma "decisão" (ainda que eles não tivessem escolha), mas aceitam todas as condições a eles impostas, inclusive o que eles chamam de "trabalho forçado" e responde que acharam "muito justa a sua proposta dentro dos direitos humanos e da justiça social. Nós até agradece a tua nobridade (sic) por estar trabalhando no teu circo". Em outra cena, tal discussão em torno do trabalho precarizado volta à tona quando, exaustos com a situação a eles imposta, os Trapalhões vão até a sala do "patrão" pedir um adiantamento ou algum dinheiro emprestado. Ele os recebe com pilhas de dinheiro em cima da mesa, advindas do lucro com sua atividade (que, inclusive, muito dependia do sucesso da trupe, carro-chefe do espetáculo) e, em uma manobra argumentativa, afirma que "a crise é geral" e não tem como arcar com um aumento - em menção à situação econômica do país em 1982 na qual os patrões põem na "conta" dos empregados a queda da margem de lucro com a crise financeira.

Após idas e vindas, percebem, com a ajuda do trapezista Frank, que estão continuamente sendo roubados pelo patrão: "vocês é que são a atração do circo. Vocês é que enchem a caixa do barão de dinheiro. Ele está explorando você, está explorando todo mundo". Ao saber de um suposto levante entre seus empregados, Barão chama Frank de "subversivo e oportunista" e decide se "livrar desse agitador", delegando a tarefa ao hipnotizador. Em meio a tal situação, os Trapalhões falam em fugir para ir atrás de alguém que pague "um salário-mínimo". Sem vislumbrar

24. Chico é creditado como argumentista ao lado de Sérgio Bardotti, Tereza Trautman, Antônio Pedro e Renato Aragão, mas o roteiro em si é de autoria de Gilvan Pereira e J. B. Tanko. 
saídas, eles se unem à filha do Barão (Karina) e fogem do circo após despistarem os capangas do barão.

A trupe vai até a "cidade grande", onde se autointitulam os "saltimbancos trapalhões”, passam a fazer seus números nas ruas e são inclusive reprimidos por policiais. Em meio às andanças, a trupe será responsável por uma pichação (“arroz e macarrão, saúde e educação”) e irá se deparar com meninos de rua, que se apresentam a eles também como artistas, perguntando o que seria preciso para serem saltimbancos - "não precisa ter nada, nem casa, nem dinheiro, nem diploma, nem sapato, nem pratão, nem certidão de nascimento, mas a gente precisa saber certinho o dó ré mi fá sol lá si dó”, diz Didi -, e é a partir deste contato com as desigualdades e as potencialidades de um horizonte de transformação social que eles irão rever seus papéis enquanto artistas. A partir das vivências na cidade, o grupo decide, então, retornar ao Circo Bartholo e lutar por aquilo que lhes era de direito, e desta vez voltam dispostos a resistir para exercer seu ofício com dignidade. Portanto, seria o circo o único lugar possível para que os artistas/cidadãos exercessem, enquanto trupe, um lugar transformador enquanto coletividade, em que educação e cultura caminham junto à luta por direitos.

Ao voltarem ao local do circo, eles vão de encontro ao Barão e enfrentam os capangas no mesmo momento em que o patrão discute com seus comparsas o hipnotizador/mágico (Assis Satã) e sua assistente (Tigrana) - e anuncia que irá traí-los para ter mais lucro. Quando o Barão reitera que não irá repartir o dinheiro, Tigresa saca uma arma e, apontando em direção a ele, diz "Barão, eu sempre gostei de homens decididos. Mas não se esqueça mulheres de decisão também fizeram a história”. Neste momento, a trupe de saltimbancos invade a sala e vai em direção ao circo de braços dados com um grupo formado por algumas dezenas de crianças e jovens com objetivo de se apropriarem do picadeiro. Tal horizonte também reverbera uma questão geracional, já que aqui são as crianças que marcam esse lugar de expansão das liberdades, o que ecoa diretamente o processo histórico brasileiro dos tempos de Abertura Política, em que o lúdico ganha um novo papel e prenuncia um novo horizonte para o país a ser experimentado através das práticas artísticas. Então lhes é anunciado que "o circo será de todos" e o Barão atira ao chão sua capa preta, símbolo de sua autoridade. O único que não cede é o mágico, que mantém seus óculos escuros sem encarar a trupe de artistas com os olhos, o que, certamente ecoa o contexto político brasileiro e a resistência de setores linha-dura de deixar o poder. É Didi quem vai ao centro do picadeiro e anuncia: "o show vai continuar". Há aqui um gesto de libertação no qual os artistas tomam o palco e o transformam em um lugar da coletividade. Não há, portanto, recuo possível, e o "povo"/juventude ocupa todo o centro da arena.

\section{VÍTIMAS DO "MILAGRE" EM OS TRAPALHÕES NA SERRA PELADA}

Realizado em 1982, dois anos após a chegada de grandes grupos de garimpeiros na região de Serra Pelada e, pouco depois, de uma intervenção federal 
na zona de garimpo à mando dos militares capitaneada pelo major Curióo ${ }^{25}$ (em maio de 1980), Os Trapalhões na Serra Pelada foi lançado em um momento em que a região não havia chegado a seu ápice em relação ao número de mineradores, o que ocorreria pouco depois ${ }^{26}$, justamente em um momento de declínio na produção, quando as "bamburradas" eram bem menos frequentes. Portanto, trata-se de um filme que ecoa toda a problemática social ligada à atividade garimpeira ${ }^{27}$ no momento em que o horizonte político ligado à questão do extrativismo mineral, recorrente no cinema brasileiro, encontrava-se muito presente nas produções audiovisuais do período, com destaque para os registros documentais captados em áreas de mineração em obras ${ }^{28}$ como A pedra da riqueza (1976), de Vladmir Carvalho, Jari (1979), de Jorge Bodanzky e Wolf Gauer, e Vivendo os tombos (ou Carvoeiros, Dileny Campos, 1977) ${ }^{29}$. Em nenhum deles, porém, o caso específico da zona de garimpo de Serra Pelada é abordado com destaque, ainda que tenha sido o caso que mereceu maior repercussão e debate, visto que a questão da mineração no sul do Pará ganhou cobertura internacional e os fatos ali ocorridos, invariavelmente, tornaram-se centro de uma disputa de narrativas com os interesses do governo autoritário no poder (que se valia da falta de regularização da área por interesses financeiros que se sobrepunham aos direitos individuais dos garimpeiros):

O surgimento de diferentes áreas de garimpos na região de Carajás ocorre pela própria presença de garimpeiros que descobrem o enorme potencial de minérios ali existentes. [...] Frente a estas descobertas, desencadeia-se a tensão entre garimpeiros e companhias mineradoras ${ }^{30}$ [...] que passam a disputar com os garimpeiros o controle da exploração mineral. E, com o aval do Estado, amparam-se neste buscando reintegração de posse, exigindo a expulsão dos garimpeiros. O sul e sudeste do Pará, região na qual se insere Serra Pelada, são marcados por projetos de colonização e por obras federais como o Projeto Grande Carajás ${ }^{31}$, atraindo grandes proprietários, agricultores e colonos, tendo também o controle do Estado como área de segurança nacional como uma das formas de enfrentamento das disputas pela terra sob várias dimensões e expressões ${ }^{32}$.

Nesta direção, o filme evita contrapor-se a esta agenda (caso da própria intervenção militar na área), mas, evocando o horizonte do autoritarismo (capitaneado por um "empresário" que toma o controle da região cuja gestualidade que faz menção direta aos nazistas), aborda de forma ampla as problemáticas sociais ligadas ao garimpo e, no desfecho, reverbera um horizonte de resistência popular quando os garimpeiros se organizam para reagir às arbitrariedades a eles impostas. Logo no trecho inicial, a ambientação de Serra Pelada é introduzida através de um conjunto de fotografias que evidenciam as condições insalubres de trabalho na mineração, seja através de planos gerais que mostram o "formigueiro humano" de Serra Pelada ou de imagens que mostram alguns garimpeiros em detalhes. Em seguida, há uma cartela que delimita especificamente tratar-se de "Serra Pelada antes da intervenção federal", a qual, ainda que situe que os problemas do garimpo ali relatados - como o trabalho semi-escravo, as frequentes mortes de garimpeiros etc. - teriam acontecido antes da chegada dos militares. No entanto, para o espectador, fica evidente que os problemas de Serra Pelada prosseguiam,
25. Interventor federal na região de maio de 1980 a 1982 cujo envolvimento e com a tortura a presos políticos e desaparecimentos forçados (desde sua ação na repressão à Guerrilha do Araguaia) é notório. Ainda em 1982, Sebastião Curió lança candidatura a deputado federal (pelo Partido Democrático Social, PDS, um dos sucessores do ARENA), sendo eleito com a promessa de lutar pela que o governo prorrogasse o garimpo na região, o que de fato se efetiva. Cabe destacar que, após sua saída como interventor militar, a área foi mantida sob o comando de um de seus homens de confiança. Ari Santos, o que manteve sua influência direta na zona de garimpo.

26. Há inúmeras inconsistências nestes dados, que em geral apontam para 80 mil homens: "A Revista do Garimpeiro afirma que a população total de garimpeiros no ano de 1983 é de 120 mil (a revista afirma, na página anterior, ser 100 mil), sendo 48 mil legais e 72 mil sem registro do Sindicato Nacional dos Garimpeiros. Kotscho informa serem 80 mil homens trabalhando no mesmo ano" (MOURA, 2008, p. 81).

27. Em especial no sul do Pará, mas que, invariavelmente, reverbera processos semelhantes ocorridos por todo país, que tiveram como um importante marco a Lei do Garimpo de 1977 imposta pelos militares e, na região, o Projeto Grande Carajás. 
28. Entre os registros audiovisuais feitos na época predominam produções em vídeo feitos para a serem veiculados naTV, o que inclui um especial do Globo Repórter (com reportagem de José Hamilton Ribeiro) feita no local em 1982, ano de lançamento do filme dos Trapalhões e, já em 1984, a reportagem conduzida por Ernesto Varela na parceria do Olhar Eletrônico com Abril Vídeo. Destaca-se ainda os documentários Motorista de Caçamba (1981-1989, Rudi Böhm, feitos a partir de uma pauta da televisão austríaca) e, também em vídeo, Montanhas de Ouro (1990, Adrian Cowell).

29. Tal questão atravessa, em maior ou menor grau, a narrativa de filmes como Cristais de Sangue (1975, Luna Alkalay), Na Terra dos Homens Maus (ou Aruã Expedito Gonçalves Teixeira, 1976), O Dia das Profissionais (Rajá de Aragão, 1976), Diamante Bruto (1977, Hermano Penna), A Tenda dos Prazeres (ou Ouro Sangrento 1978, César Ladeira

Filho), Tem Piranha no Garimpo (1978, José Vedovato), Cordão de Ouro (Antonio Carlos Fontoura, 1978), Maneco, o super tio (Flávio Migliaccio, 1978), O Rei da Boca (Clery Cunha, 1982), Insaciados (Líbero Miguel 1981), As Pipas (ou O Sexo e as Pipas, José Vedovato, 1981) e Memórias do Medo (Alberto Graça, 1981).

30. Não apenas com a Companhia Vale do Rio Doce, que assumiria a área, mas também com interesses de mineradoras estrangeiras interessadas em explorar a região, dado o seu enorme potencial previsto.

31. Em relação a isto, vale destacar a importância dos registros contido no filme institucional Projeto Carajás (1980), produção da CVRD através de sua subsidiária Amazônia Mineração S.A. realizado por Jorge Bodanzky e Suzana Amaral (com fotografia de Pedro Farkas) que detalha os planos do Estado brasileiro na região. fazendo dessa cartela mero adereço de importância lateral, para não criar problemas com o governo, enquanto o que se vê é um universo de exploração e miséria.

Soma-se a isto o fato de o personagem de Renato Aragão chamar-se Curió, que é ali homenageado, talvez como estratégia de proteção ou mesmo um aceno aos militares, sem que qualquer ponto em comum entre suas trajetórias seja ao menos justificado. Os outros trapalhões também têm nomes que fazem menção à atividade do garimpo: Melexete (Mussum), cujo nome, referência à lama resultante da lavagem de cascalho no garimpo, ganha uma conotação racista ${ }^{33}$, Boroca (Dedé Santana), gíria usada para se referir à bolsa usada pelos garimpeiros para irem ao trabalho, e Bateia (Zacarias), ferramenta utilizada para separar o ouro e outros metais dos sedimentos contidos em locais com água. Logo somos apresentados aos protagonistas, no instante da chegada do quarteto até a área de mineração, quando veem com certo espanto o tamanho e a profundidade do local: "Cheguei, vi, gostei e me bestifiquei”, diz Melexete (Mussum). Em meio àquele local caracterizado pela precariedade da mão de obra, os Trapalhões se "integram" à paisagem (as escadas de madeira, os fluxos de garimpeiros em direção à locais cada vez mais profundos da área de mineração) e são logo interpelados por um homem ${ }^{34}$, quando, antes que possamos ver seu rosto, suas botas de couro pisam propositalmente nas mãos de Curió (Renato Aragão). Neste momento, o sujeito questiona como eles teriam chegado até ali sem serem vistos, quem os teria autorizado a lavrar naquela área e, em tom de ameaça, estabelece as "regras" para que eles pudessem trabalhar, as quais impossibilitariam que eles tivessem qualquer chance de enriquecer com o próprio trabalho: o grupo deveria vender o ouro a preço de prata a ele e destinar diretamente trinta por cento dos lucros ao patrão. Além disso, para se manterem lá deveriam comprar alimentos e bebidas dos "patrões", também comercializados ao preço da prata. Na corrida do ouro, não há lugar para o sonho de um futuro melhor, mas se impõe um regime opressivo que aprisiona aqueles que foram em busca de riquezas. Tais questões ecoam diretamente o contexto em que o filme foi realizado, quando "a presença dos militares no garimpo disciplinando, normatizando e controlando o trabalho e as relações sociais, faz nascer à figura do furão (garimpeiro ilegal)" "35, trabalhadores que tinham de caminhar por dias, em trilhas

[...] partindo do km 30 da PA-150 (hoje Curionópolis). [...] Muitos morriam antes mesmo de chegar à mina. Os que sobreviviam tinham que se submeter aos piores trabalhos por sua condição de ilegal. Uma das dificuldades em precisar a população de garimpeiros é justamente a ausência de registros e as próprias idas e vindas desses trabalhadores ${ }^{36}$.

Ao fim do primeiro dia na lavra de garimpo, os Trapalhões recebem uma "conta" pelo dia de trabalho e são informados de que já têm uma dívida de "1 milhão e 320 mil cruzeiros" a ser paga imediatamente. Bateia (Zacarias) pergunta se o valor tão alto seria devido à "inflação", ecoando diretamente o contexto em que o filme foi realizado, e quando Curió (Didi) responde que seria um "roubo", Melexete (Mussum) prontamente afirma que eles jamais conseguirão sair dali. Para além dos trabalhadores braçais, o conflito se estende para aqueles que 
detêm áreas de lavra de ouro, sobre as quais um grupo liderado pelo "estrangeiro" Von Bermann (Felipe Levy), pouco a pouco, por meio de diferentes formas de coação, tenta assumir o controle e, em paralelo, criar um sistema que lhe permitisse remeter o ouro encontrado por meio de um porto clandestino que não estivesse no radar das autoridades para não pagar impostos. Para este projeto de poder, o grupo ameaça de morte aqueles que estão no seu caminho, o que inclui também um comerciante da região, Ribamar (Castro Gonzaga), e Chicão (Gracindo Júnior), seu filho, que tem um bar no local onde o grupo quer construir o porto. Além disso, eles se unem, também por meio de coação, às autoridades locais, em especial um tabelião, Rufino (Wilson Grey), que frauda documentos de posse das terras.

Obrigados a fugir para que não tivessem que se submeter aos detentores do poder, os Trapalhões, perseguidos pelos "mercenários" chefiados por Von Bermann vão até o ponto comercial de Ribamar e este, na manhã seguinte, é atacado pelos capangas, que sequestram o proprietário, com o qual os Trapalhões irão se solidarizar e partir em busca de seu paradeiro. Em meio à situação, a filha do tabelião, Lilian (Louise Cardoso), apaixonada por Chicão e "prometida" a Von Bermann, toma conhecimento das ilegalidades cometidas pelo pai, que estavam justamente prejudicando seu amado, e o questiona sobre os documentos que tinha encontrado, o que introduz uma discussão sobre a questão agrária e a grilagem de terras. Perguntado sobre o significado do temo "usucapião", ele reponde tratar-se do "modo pelo qual o colono se torna, pacificamente, o proprietário de suas terras", o que faz com reaja relatando as evidentes injustiças ocorridas com frequência na região, prontamente negadas por ele ("o Incra ${ }^{37}$ garante o título de propriedade"). Ao receber Chicão, o tabelião tenta mentir a ele que seu pai havia vendido a fazenda a Von Bermann para esconder que ele mesmo havia falsificado a documentação. Lilian intercede logo após Chicão deixar, furioso, o escritório do tabelião e pede ao pai para que ele deixe de cometer ilegalidades "que prejudicam tanta gente", ao que ele responde dizendo que não há nada que possa fazer por "estar comprometido demais" e que, por isso, "já não pode parar".

A questão indígena na região é abordada em diversas ocasiões, mas ganha centralidade por meio de um garoto indígena, Caú (Nilson Silva) que, vivendo próximo ao bar de Ribamar, se aproxima do grupo, cuja caracterização estereotipada lembra as mais diversas representações de personagens semelhantes no universo publicitário $^{38}$ e ecoa esse horizonte de "integração" dos discursos oficiais, como visto na cena em que, após o personagem pedir que Curió "fique com ele”, este reponde que ele precisa "ir pra escola, aprender a ler e a escrever". Por outro lado, tal caracterização simplista não deixa de guardar certa ambiguidade, já que Caú irá resistir junto ao grupo contra a opressão daqueles que lhes retiraram a terra e, invariavelmente, o deixaram nesta situação, isolado de sua tribo e vivendo na beira da estrada situada na direção da zona de garimpo.

Lilian, obrigada a se casar com Von Bermann, é levada até a casa do vilão, local onde Ribamar está mantido em cativeiro. Os Trapalhões, o menino Caú e Chicão vão até lá para resgatá-los e, sentindo-se ameaçado, Von Bermann, por insistência de seu comparsa, decide fugir com o ouro. Neste momento, seus planos são frustrados por grande levante dos garimpeiros que, com pás e enxadas nas mãos, rebelam-se contra
32. MOURA, Salvador Tavares de. Serra Pelada: experiência, memórias e disputas. 2008. 119 f. Dissertação (Mestrado em História) PUC-SP, São Paulo. p. 40.

33. Os garimpeiros "referem-se a uma lama pastosa chamada de melexete, que deixava o trabalhador da cor do solo do garimpo" (MOURA, 2008, p. 79).

34. O qual, pouco depois, saberemos tratar-se do capanga Bira (Eduardo Conde).

35. MOURA, Salvador Tavares de. op. cit., 2008. p. 49.

36. Ibidem, p. 50.

37. Instituto Nacional de Colonização e Reforma Agrária, criado em 1970. No contexto da região, dado o agravamento do conflito agrário, foi criado o Grupo Executivo para a Região do Baixo Amazonas (GEBAM), subordinado ao Conselho de Segurança Nacional.

38. Caso do logo da TV Tupi, por exemplo. 
39. As canções foram adaptadas por Arnaud Rodrigues, que assina a direção musical, e o roteiro, para além do co-diretor Victor Lustosa e do próprio Renato Aragão, inclui novamente a colaboração de Gilvan Pereira.

40. A primeira versão foi lançada em 1939, com direção de Victor Fleming; Oróz faz menção à cidade de Orós localiza no Ceará, estado de origem de Renato Aragão.

41. Cabe destacar que as consequências ocorreram de forma desigual, algumas delas mais duradoras. Episódio semelhante ocorrera, com gravidade, em 1970 com implicações "nefastas para a região, as quais iam à contramão do projeto do Brasil Grande, proposto pelos militares. A saída inicialmente encontrada foi tentar mascarar a gravidade da situação, uma vez que este quadro não era compatível com a imagem do 'novo Nordeste' cultivada e divulgada pelos militares" (COLOMBO, Luciléia. A Sudene e a mudança instituciona no regime militar. Cadernos do Desenvolvimento, Rio de Janeiro, v. 8, n. 13, p. 155 156, 2013.p. 160)

42. Ibidem. comunicação \& educação • Ano XXVI • número 1 • jan/jun 2021

o regime autoritário ao qual tiveram que se submeter. Pela adesão que tal movimento tem, a mina é inclusive mostrada vazia, de forma a ressaltar a união dos garimpeiros para lutar por seus direitos. Em paralelo, os trapalhões e Chicão organizam um plano para capturar Von Bermann, auxiliados pelas tropas do exército que chegam ao local (cujas imagens foram, como informa a cartela, cedidas por Jean Manzon e que tem um caráter belicista que destoa muito das cenas que as antecedem). Cabe destacar que, ainda que o filme recorra a esta chegada triunfante do exército, são os trabalhadores que se rebelam e clamam por mudanças sociais e, desta forma, a chegada ou não dos militares pouca diferença faz ao desenlace da trama.

Em seu protesto contra as condições a eles impostas para exercerem sua profissão de maneira digna, o grupo vai até a frente da casa de Von Bermann e, em uníssono, branda “queremos justiça social, o fruto do nosso trabalho!". Reprimidos pelos "seguranças"/capangas enquanto o vilão observa tudo de sua janela, o grupo entra em confronto com os opressores. O ouro é finalmente resgatado e Ribamar é solto do cativeiro. Impelido a discursar aos manifestantes, Curió (Renato Aragão) traduz um discurso dito às escondidas pelo tabelião: "A justiça será feita. Ao trabalhador se fará justiça com o fruto do seu trabalho. Lutaremos a favor dos fracos e oprimidos. Nós garimpeiros lutaremos lado a lado à cata do ouro. Os maus serão expulsos da terra e tudo será dentro da lei, com justiça verdadeira."

Por fim, os garimpeiros são avisados por Chicão que agora terão "direito a um pedaço de terra" e que lá haveria "ouro pra todo mundo". Mesmo com a boa notícia, Curió, migrante nordestino, decide "ir embora pra São Paulo trabalhar de pedreiro; o ouro já fez muita confusão", e após dizer isso encontra uma grande pepita de ouro. Cabe destacar que, mesmo com tal desfecho redentor, é o aspecto de uma conquista de direitos pela coletividade que dá o tom e, portanto, pensado no contexto da Abertura Política, o filme, ainda que particularizado na questão do garimpo, aponta para um horizonte mais amplo de justiça social através da luta por direitos (neste caso, através do levante dos mineradores) e ecoa diretamente um momento de reorganização das associações de classe nos mais diversos setores.

\section{OS TRAPALHÕES E O MÁGICO DE OROZ E O UNIVERSO NORDESTINO}

Os Trapalhões e o Mágico de Oroz ${ }^{39}$ (Dedé Santana e Victor Lustosa, 1984) traz uma fábula em relação ao problema da seca no nordeste, costurado em meio a inúmeras referências apropriadas de $O$ Mágico de $O z^{40}$. Realizado logo após um período de longas secas que perdurou entre 1979 e 1983-1984 ${ }^{41}$, que agravou os "os baixos índices de desenvolvimento na região [...] e que trouxe novamente a região para o palco das grandes discussões nacionais" ${ }^{\text {"2 }}$, o filme é introduzido por uma sequência de fotografias que retratam os problemas sociais na região nordeste, $\mathrm{e}$ logo somos confrontados com dados sobre a miséria e as desigualdades sociais em voice over: "25 milhões de habitantes. Quase um continente esquecido. Nordeste. Massa de um todo que a seca reduziu a pó. Resto de verde. Resto de mundo. 


\section{A abertura política através de Os Trapalhões \\ - Maria Ignês Carlos Magno, André Gustavo de Paula Eduardo e Felipe Abramovictz}

Resto de esperanças. Resto de gente. Resto de vida em um lugar em que a vida se confunde com a morte". A voz prossegue: "Por mais que grite, este homem não consegue ser ouvido. Suas esperanças vão se diluindo à medida que aumenta a surdez dos homens insensíveis e o povo carece da prece, pois acredita que o Nordeste não é uma terra sem deus".

Aqui nos são fornecidos dados reais sobre a seca e há críticas diretas às respostas por parte do Estado, pouco efetivas ${ }^{43}$, muitas vezes com planos elaborados sem "menção quanto à área de atuação nem ao público-meta" ${ }^{\text {, }}$ com uma "falta de articulação institucional" ${ }^{5}$, uma "defasagem considerável entre recursos programados e efetivamente liberados" ${ }^{\prime 6}$ e sem disponibilizar publicamente dados sobre os resultados concretos para além das projeções iniciais. No caso dos projetos de irrigação, segundo Nivalda Aparecida Campos, "tais programas teriam como premissa básica a manutenção do sistema de propriedades, [...] de forma a não contrariar os interesses dominantes, e ainda, propiciar o maior número de ganhos para os proprietários de terras" ${ }$. Desta forma, para os grandes latifundiários, a maior "disponibilidade de água [...] servia para valorizar as terras, aumentando, desproporcionalmente ao investimento direto feito pelos proprietários, seu preço de arrendamento" ${ }^{\$ 8} \mathrm{e}$, com isso,

[...] ratificam o status quo existente uma vez que não tocam nas questões que de fato são importantes para a transformação das condições materiais de existência dos segmentos que mais sofrem os efeitos das secas. E além de não avançar na solução dos problemas, os programas implementados ainda têm reflexos negativos diretos tanto econômicos quanto socialmente ${ }^{49}$.

Além disso, tal plano inclui, por ação da Sudene, a criação de Frentes de Emergência, que recrutavam trabalhadores para obras hídricas que, ainda que criadas parcialmente com dinheiro público, muitas vezes eram realizadas dentro de propriedades privadas que "acabavam por beneficiar apenas os proprietários de terras, na maioria das vezes os médios e grandes ${ }^{50}$, inviabilizando o uso social da água" ${ }^{51}$. Segundo Campos, tal

[...] intervenção nos períodos de seca têm como principal finalidade evitar uma convulsão social na área. Apesar dessa finalidade estar citada inclusive nos próprios relatórios do governo federal, as invasões de cidades e o grande número de saques no comércio local ocorridos no período, demonstram o fracasso das frentes com relação também a esse fim ${ }^{52}$.

Em O Mágico de Oróz, o protagonista Didi (Renato Aragão), um trabalhador precarizado de um canavial, logo nos é apresentado, assim como sua ambição de lutar por um futuro melhor depois de "cinco anos de sofrimento, sem chuva, sem fruta, sem caça e sem esperança de melhora”. Neste horizonte, o personagem, um retirante ingênuo e sonhador (assim como Dorothy, da história original), decide partir de sua terra com um grupo de companheiros, Soró (Arnaud Rodrigues) e Tatu (José Dumont) e, na migração, eles levam a casa de pau a pique na carroça (o que, neste contexto reverbera como os personagens carregavam consigo toda uma herança cultural durante seu êxodo para a "cidade") e unem-se a duas estranhas

43. O que incluía a implementação de um Programa de Irrigação e do PROHIDRO (Programa de Aproveitamento de Recursos Hídricos) e, alguns anos depois do Projeto Nordeste (1982) como comenta Campos, que destaca a pouca efetividade das ações governamentais. CAMPOS, Nivalda Aparecida. A grande seca de 1979 a 1983: um estudo de caso das ações do governo federal em duas sub-regiões do estado do Ceará (Sertão Central e Sertão de Inhamuns). 2004. 174 p. Dissertação (Mestrado em Ciências Sociais) - Ufscar, São Carlos, 2004, p. 17.

44. Ibidem. p. 25.

45. Ibidem. p. 28.

46. Ibidem. p. 36

47. Ibidem. p. 30

48. Ibidem. p. 33

49. Ibidem. p. 34

50. Para propriedades de mais de 500 ha, por exemplo, era oferecido o investimento " $50 \%$ do Governo Federal a fundo perdido com a mão-de-obra e os $50 \%$ restantes por conta do proprietário, que também dispunha da mesma linha de crédito de emergência". Pagos por diária, o salário dos trabalhadores das Frentes, financiadas pelo Estado brasileiro, em média, "correspondia a 1/3 do salário mínimo nacional", Como resultado, "ao encerrarem-se as Frentes [...] tem-se as propriedades valorizadas e os trabalhadores novamente sem ocupação, se encontrando numa situação igual ou pior do que antes". lbidem. p. 48-74.

51. Ibidem. p. 45 52. Ibidem. p. 63 
figuras em suas buscas: um espantalho (Zacarias) que sonha ter um cérebro e um homem de lata (Mussum), cujo desejo é possuir um coração. Aqui, como em todo o cinema dos Trapalhões, as referências que costuram a trama original permanecem presentes de forma a serem reconhecidas pelo público em um jogo intertextual que deglute o referencial. É esta alusão ao mote do original, recorrente e fragmentária, que guia a narrativa de forma a se apoiar em um pacto com o espectador com aquilo que era previamente conhecido. No caso de Oróz, isso se dá tanto na abertura, quando, diferentemente de Dorothy, há um Didi que, faminto, atira-se com uma catapulta em direção a urubus, que compõem um cenário desolador, ou mesmo na maneira como, diferentemente do original, a casa não é atingida por um vendaval, mas levada em um burro que leva os migrantes em busca de um futuro melhor. Desta forma:

A história original estabelece com os filmes uma relação sempre frouxa, fluida, tornando-se no decorrer da narrativa apenas uma longínqua referência. $\mathrm{O}$ título e abertura procuram abrir apenas o diálogo com o espectador utilizando um repertório já conhecido, mas em seguida os filmes trilham um caminho próprio, numa adaptação 'selvagem' do imaginário ficcional de origem ${ }^{53}$.

No caminho, com sede e fome, eles furtam mantimentos em uma propriedade de uma pequena cidade (Oróz) e distribuem com algumas crianças do povoado. Flagrados por um grupo de capangas, são sentenciados a um castigo em praça pública pelo delegado local, Leão (Dedé Santana), aliado ao poder, que se usa da postura autoritária para esconder sua própria covardia ("venho aqui em praça pública impor um castigo a esses criminosos que ousaram invadir a fazenda do nosso querido coronel Ferreira. E para que invadiram esta fazenda? Pra roubar um copo d'água!"). Enquanto anuncia a sentença, uma professora local (Xuxa Meneghel), por quem Leão é apaixonado, o interpela e o chama publicamente de "covarde" e de "capanga do coronel Ferreira", ao que ele responde: "você acha que eu vou ficar contra o coronel? Até o juiz está do lado dele”. Em meio à confusão, o coronel (Maurício do Valle), que assistia à cena, oferece suspender o castigo se ela se casar com ele e, além disso, permitiria, em contrapartida, que os alunos da escola em que ela dá aula tivessem acesso à água. Ela prontamente nega e, olhando tanto para o delegado quanto para os homens que "protegem" o latifundiário, retruca que "valente cercado de capanga não é valente, é um covarde disfarçado". Em resposta, o delegado, pressionado pelo coronel, diz estar com seus "macacos" (referência aos agentes da repressão) e termina de pronunciar seu arbitrário veredicto, acusando-os de roubo. Pouco a pouco, porém, o delegado, decidido a mostrar que tem coragem para conquistar o coração da professora, decide impor uma pena alternativa, na qual todos estariam livres caso ajudassem a trazer água para a cidade; o grupo, então, formado por Didi, homem-lata e o espantalho, sai pelo sertão acompanhado pelo próprio Leão.

É a partir daí que se evidencia a lógica do sistema repressivo imposto pelo coronel à população, pois ele, detentor do monopólio da água, tornava todos subservientes às suas ordens por meio da violência. No único poço de água da cidade, forma-se uma grande fila e, para além de cobrar dos moradores para que tenham acesso à fonte, o latifundiário exige que os habitantes votem no candidato 
por ele indicado para que ele possa manter o poder político local. Em uma das cenas, quando surge uma mulher sem condições de pagar pelo que consome, um dos capangas pergunta se ela não teria a menos um título de eleitor para oferecer como "pagamento" (o que sugere a manipulação do processo eleitoral, por meio do voto de cabresto) e, ao saber que ela seria analfabeta de pai e mãe, a expulsa imediatamente ao ver que ela não teria "nada a oferecer" àquela estrutura de poder. Didi, ciente das arbitrariedades ali cometidas, reitera que "água não se vende, se é de Deus, é nosso". Ele e seus companheiros partem pelo sertão em busca de outros poços de água. No caminho, se deparam com um suposto beato/mágico, mas este não se rende a soluções messiânicas e adverte:

Os homens prometeram aos homens do sertão que podiam plantar e com água eles iriam irrigar. Não é com reza, nem com promessa nem com um mágico charlatão que vai se fazer chover no sertão. Conta-se que [...] em época de eleição aparece um monstro de metal que, torcendo a sua orelha, jorra água em sua boca.

Após esta referência a como as estruturas de poder coronelistas manipulam o processo eleitoral a partir da miséria, o mágico, por fim, pede a Didi que "siga sempre em frente, lutando se preciso for, mas sem perder a sensibilidade", o que é reforçado por uma canção que evoca um horizonte de resistência (cujo destaque se dá pelo refrão, “o que é seu ninguém pode tirar”). Advertidos com as considerações do mágico, o grupo segue seu rumo até uma grande capital do sudeste (no filme, o Rio de Janeiro), cuja realidade é completamente distinta daquela que os personagens viviam. Tal gesto que supostamente completaria, ainda que de forma temporária, a migração dos personagens, não se concretiza e a visão que os personagens têm da cidade é medida pelas experiências que o trajeto em busca de um futuro melhor lhes apontou. Portanto, o espaço urbano é logo codificado como um lugar de contrastes sociais e desigualdades: do "progresso" faraônico da ponte Rio-Niterói (obra realizada na Ditadura Militar, iniciada em 1968 e concluída em 1974) aos ambulantes no largo da Carioca, de uma menção aos migrantes nordestinos aos artistas de rua que perambulam pelas ruas do centro.

Por fim, o grupo encontra uma fonte pública, uma "tecnologia da cidade" e resolvem levá-la para a cidade do sertão de onde vieram para resolver o problema da seca que os afligia no regime autoritário imposto pelo Coronel. Porém, ao instalá-la na pequena praça do vilarejo, a água não vem, o que, de alguma forma, se conecta com a afirmação do mágico de que não haveria soluções simplistas de salvadores da pátria. Diante do fracasso, os personagens são novamente presos e, desta vez, colocados em um pau-de-arara, instrumento de tortura que além de reforçar o sistema repressivo ali imposto pelos detentores do poder econômico, ecoa o horizonte político do país. Sem alternativas e observados por toda a população que assiste, impassiva, à cena, eles decidem que nada lhes resta a não ser se unirem em uma última tentativa de esperança no porvir, o que, diante de um futuro sombrio que se avizinhava para eles, mostra-se um potente ato de resistência. Neste instante, cada um deles percebe as potencialidades que tinham em si mesmo (o que inclui 
a busca do homem-lata por um coração e do espantalho por um cérebro) e se dão conta de que devem lutar coletivamente para transformar o mundo onde vivem:

coragem a gente aprende a ter, é só dizer: eu quero, eu posso. [...] Quando se é justo e decente, se muda aquilo que a gente quer. Vamos pensar firme, vamos todos pensar forte. Pra cair um pingo d'água e mudar a nossa sorte.

Pouco a pouco, aqueles que os assistem passam a se engajar e repetir os versos entoados pelo grupo e, em meio a tal potência advinda da união do povo, inesperadamente começa a chover na cidade. A população comemora, em delírio, o que inclui mais uma metáfora sobre a liberdade: um pássaro solto de uma gaiola nas mãos de Zacarias.

Por fim, tal horizonte de transformação volta-se novamente, por meio de uma cartela de texto, para a questão da seca ("E choveu... Que a chuva que molhou o sofrido chão do nordeste não esfrie o ânimo de nossas autoridades na busca de soluções para a seca / Os Trapalhões”) e ali a potência transformadora de resistência popular é simplificada a uma menção que acaba pondo em dúvida o próprio lugar utópico de luta para o qual o filme aponta e volta a destacar o papel do Estado neste processo. Apesar disso, é preciso destacar que, ainda que o referido intertítulo que antecipa os créditos finais se concentre em tal problemática em particular, o desfecho do filme aponta um olhar mais amplo sobre desigualdades brasileiras, as noções de progresso, a reconfiguração dos espaços de poder autoritários pelas forças de organizações populares e, por fim, um horizonte futuro de transformação e de reempoderamento, o que ecoa diretamente os rumos do país na redemocratização durante a Abertura Política.

\section{CONSIDERAÇÕES FINAIS}

A partir dos filmes aqui referidos, há que se destacar como o cinema, um lugar, por excelência, “das construções e projeções do imaginário, da aferição de sensibilidades e práticas sociais" ${ }^{54}$ tem muito a nos revelar sobre os processos históricos. Em produções como estas nas quais o humor se vale, em distintas ocasiões, de uma relação direta com o contexto do país de forma ampla - o que, ainda que de forma pontual, resvala em uma crônica política de acontecimentos de destaque no noticiário (caso de garimpo no sul do Pará em Serra Pelada, por exemplo) -, nota-se, nos três filmes abordados, desfechos que apontam para o reempoderamento popular em reação direta a situações de opressão vividas por trabalhadores.

Nota-se também que, ainda que seja especialmente destacada em Oroz, a questão da migração atravessa os três filmes, visto que - tanto o sertanejo e seus companheiros que saem do nordeste para tentar a vida no sudeste em Os Trapalhões e o Mágico de Oroz, quanto os artistas mambembes que vão tentar a vida na cidade

54. SCHVARZMAN Sheila. Humberto Mauro e as imagens do Brasil. São Paulo: Unesp, 2004. p. 18. grande em Saltimbancos e os quatro sujeitos que migram de sua cidade de origem para trabalhar no garimpo em Serra Pelada -, explicitam a temática social advinda dos deslocamentos populacionais (seja do Nordeste para o Sudeste, dos interiores 
rurais para as grandes capitais ou mesmo daqueles que cruzaram, em situações precárias, o país em busca do sonho do "ouro").

Tais horizontes aos quais os filmes apontam, porém, chegam a desfechos distintos em cada um deles, e, portanto, há particularidades que devem ser destacadas. Os saltimbancos Trapalhões, neste aspecto, é aquele em que o reempoderamento popular se efetiva de forma mais completa e é o povo que ocupa o centro do picadeiro. Em Oroz, ainda que o tal aspecto seja latente no desfecho do filme, não há propriamente uma transformação no tecido social (já que o regime opressivo não é destituído, ainda que momentaneamente perca forças) e no caso de Serra Pelada, que entre eles evoca um tema menos pacificado (visto que o número de garimpeiros na região estava no auge e as ações dos militares permaneciam), as ambiguidades do discurso caracterizam a trama, ainda que esse lugar "chapa branca" em nenhum momento anule ou se sobreponha ao levante popular entre os garimpeiros no desfecho.

Conclui-se, portanto, que mesmo apontado resoluções distintas entre si, é a forma como o pensamento do filme evoca a derrocada do autoritarismo por meio de um levante popular que os diferencia de inúmeros outros filmes estrelados pela trupe lançados durante a Abertura Política, pois nas três obras destacadas, tal anseio por mudanças sociais vai além das inúmeras menções a fatos do cotidiano brasileiro presentes em toda a filmografia dos Trapalhões (das conquistas no futebol à escola campeã no carnaval, dos lançamentos de filmes estrangeiros no cinema às novelas e minisséries televisivas em exibição, do choque do petróleo à inflação, das greves ao arrocho salarial, assuntos comuns em filmes da trupe). Lançados em um momento em que a luta política chegava às ruas ${ }^{55}$, tais filmes apontam para um anseio por transformação que estava no ar naquele momento no país, em que tudo apontava para uma marcha irreversível rumo à redemocratização.

\section{REFERÊNCIAS BIBLIOGRÁFICAS}

CAMPOS, Nivalda Aparecida. A grande seca de 1979 a 1983: um estudo de caso das ações do governo federal em duas sub-regiões do estado do Ceará (Sertão Central e Sertão de Inhamuns). 2004. Dissertação (Mestrado em Ciências Sociais) - Universidade Federal de São Carlos, São Carlos, 2004. Disponível em: https://repositorio.ufscar.br/bitstream/handle/ufscar/1484/DissNAC. pdf?sequence=1\&isAllowed=y. Acesso em: 5 ago. 2020.

CARRICO, André. Os Trapalhões no Reino da Academia: revista, rádio e circo na poética trapalhônica. 2013. Tese (Doutorado em Artes) - Unicamp, Campinas.

COLOMBO, Luciléia. A Sudene e a mudança institucional no regime militar. Cadernos do Desenvolvimento, Rio de Janeiro, v. 8, n. 13, p. 153-175, 2013. Disponível em: http://www.cadernosdodesenvolvimento.org.br/ojs-2.4.8/ index.php/cdes/article/view/142/143. Acesso em: 18 out. 2020.

MELO, João Batista. Lanterna mágica: infância e cinema infantil. Rio de Janeiro: Civilização Brasileira, 2011.

55. O que inclui a reorganização das organizações de classe, o movimento das Diretas Já, as conquistas sociais dos movimentos grevistas etc. 
comunicação \& educação • Ano XXVI • número 1 • jan/jun 2021

MOURA, Salvador Tavares de. Serra Pelada: experiência, memórias e disputas. 2008. Dissertação (Mestrado em História) - Pontifícia Universidade Católica, São Paulo. Disponível em: https://tede2.pucsp.br/handle/handle/13071. Acesso em: 19 set. 2020.

RAMOS, José Mario Ortiz. Cinema, televisão e publicidade: cultura popular de massa no Brasil nos anos 1970-1980. São Paulo: Annablume: 2004.

SCHVARZMAN, Sheila. Humberto Mauro e as imagens do Brasil. São Paulo: Unesp, 2004. 